\title{
Profil Pemahaman Himpunan oleh Siswa Berdasarkan Perbedaan Kemampuan Matematika Ditinjau dari Teori APOS
}

\author{
Maya Winarsih $^{1 *}$ dan Helti Lygia Mampouw ${ }^{2}$ \\ $1^{*}, 2$ Pendidikan Matematika, Universitas Kristen Satya Wacana \\ Jalan Diponegoro No. 52-60 Salatiga, Jawa Tengah, 50711, Indonesia \\ 1*202015056@student.uksw.edu, 2helti.mampouw@uksw.edu
}

Artikel diterima: 16-04-2019, direvisi: 26-05-2019, diterbitkan: 31-05-2019

\begin{abstract}
Abstrak
Penelitian yang dilakukan oleh PISA menunjukkan bahwa pemahaman konsep siswa masih tergolong rendah terutama pada materi himpunan yang merupakan ilmu dasar dari semua cabang ilmu matematika. Tujuan penelitian ini untuk mengungkap profil pemahaman materi himpunan oleh siswa berdasarkan perbedaan kemampuan matematika ditinjau dari teori APOS. Subjek terdiri dari 3 siswa kelas VIII MTs Negeri Ngablak Magelang dengan kemampuan matematika tinggi, sedang dan rendah. Peneliti sebagai instrumen utama dibantu soal tes mengenai himpunan dan pedoman wawancara. Hasil yang diperoleh adalah siswa berkemampuan matematika tinggi berada pada level skema trans karena mampu melakukan aksi, proses, objek dan skema. Siswa berkemampuan matematika sedang berada pada level skema inter karena mampu melakukan aksi dan proses namun belum mampu menghubungkan objek dengan skema. Siswa berkemampuan matematika rendah berada pada level skema intra karena mampu melakukan aksi namun mengalami kesulitan pada bagian proses sehingga tidak dapat membangun suatu objek. Perbedaan level kemampuan matematika siswa sebanding lurus dengan perbedaan kemampuan pemahaman himpunannya

Kata Kunci: Himpunan, Kemampuan Matematika, Teori APOS.
\end{abstract}

\section{Profile of Students' Understanding about Set Based on Difference of Mathematical Ability Using APOS Theory}

\begin{abstract}
Research conducted by PISA shows that understanding students' concepts is still low, especially in set material which is the basic science of all branches of mathematics. The purpose of this research is to describe the profile of understanding set by students based on the difference of mathematical abilities in terms of APOS theory. The subjects consisted of 3 eighth grade students of MTs Negeri Ngablak Magelang with high, medium, and low in mathematical ability. The researcher as the main instrument is assisted with test questions and interview guidelines. The results obtained a student with high mathematical abilities is at the trans's scheme level, because she can carry out actions, processes, objects, and schemes. The Student with medium mathematical abilities is at the inter's scheme level because he can carry out actions and processes but has not been able to connect objects with schemes. The student with low mathematical abilities is at an inter's scheme level because he can take action but has difficulty in the process so that he cannot build an object. The difference in the level of students' mathematical abilities is equal to the difference in the understanding ability of the set Keywords: Set, Mathematical Ability, APOS Theory.
\end{abstract}




\section{Pendahuluan}

Pemahaman konsep merupakan kunci utama dari suatu pembelajaran (Mulyani, Indah, \& Satria, 2018). Menurut Asyhuri (Lisnani, 2019), pemahaman konsep adalah suatu proses atau kemampuan seseorang mendalami makna dari suatu topik atau permasalahan tertentu. Matitaputty mengatakan bahwa konsep dalam matematika memiliki keterkaitan antara konsep yang paling sederhana dengan konsep-konsep yang lebih kompleks sehingga pemahaman konsep sangat penting untuk dikembangkan (Puspita \& Ratu, 2019). Sementara menurut Dini, Wijaya, dan Sugandi (2018), kemampuan pemahaman sangat diperlukan untuk menguasai materi matematika sehingga siswa dapat secara utuh dan terampil menggunakan berbagai prosedur didalamnya secara fleksibel, akurat, efisien dan tepat.

Kemampuan pemahaman matematis adalah kemampuan mengklasifikasikan obyek-obyek matematika, menginterpretasikan gagasan atau konsep, menemukan contoh dari sebuah konsep, dan menyatakan kembali konsep matematika dengan bahasa sendiri (Muna \& Afriansyah, 2016). Kemampuan pemahaman matematis siswa di Indonesia dapat diketahui melalui hasil penelitian Programme for International Students Assessment (PISA). Menurut PISA, kemampuan pemahaman matematika Indonesia mengalami peningkatan dari 375 poin pada tahun 2012 meningkat menjadi 386 poin di tahun 2015 (OECD, 2016). Meskipun demikian, menurut hasil PISA tersebut performa siswa-siswi Indonesia bidang matematika masih tergolong rendah. Skor PISA siswa Indonesia mata pelajaran matematika berada pada tingkat 63 dari 69 negara yang dinilai pada tahun 2015 (Nizam, 2016).

Seorang siswa dikatakan paham suatu materi jika mampu memahami materi atau ilmu dasarnya terlebih dahulu. Salah satu ilmu dasar matematika adalah himpunan. Himpunan adalah ilmu dasar semua cabang matematika (Marsudi, 2011). Himpunan (set) adalah kumpulan dari objek-objek yang dapat didefinisika dengan jelas. Himpunan biasanya dinotasikan oleh huruf kapital, seperti A, B, C, ..., Z dan elemen atau anggota himpunan disajikan dengan huruf-huruf kecil (Marsudi, 2011). Menurut Permendikbud No 24 tahun 2016 Lampiran 15 tentang kompetensi inti dan kompetensi dasar pada materi pokok himpunan jenjang sekolah menengah pertama siswa diharapkan dapat menjelaskan himpunan, himpunan bagian, himpunan semesta, himpunan kosong, komplemen himpunan, dan melakukan operasi biner pada himpunan menggunakan masalah kontekstual. Penguasaan konsep pada himpunan dan implementasinya sangat penting karena semua cabang matematika tertumpu pada konsep dasar dan teori himpunan.

Penelitian tentang pemahaman himpunan oleh siswa sudah banyak diteliti.

Mosharafa: Jumal Pendidikan Matematika Volume 8, Nomor 2, Mei 2019 Copyright $\odot 2019$ Mosharafa: Jurnal Pendidikan Matematika 
Asih (2018) meneliti di MTs Negeri 2 Surakarta menemukan bahwa siswa masih bingung dengan langkah-langkah pengerjaan dari suatu soal cerita, antara lain: tidak menuliskan apa yang diketahui dan apa yang ditanyakan, siswa belum dapat membedakan simbol himpunan seperti simbol irisan dan gabungan, siswa tidak dapat menggunakan rumus himpunan dengan tepat pada suatu soal cerita, dan siswa tidak dapat menarik suatu kesimpulan. Adilistiyo (2017) menemukan bahwa kesalahan oleh siswa SMP kelas VII ditinjau dari kesalahan Newman pada materi himpunan meliputi: kesalahan dalam memahami sebuah soal karena siswa belum mampu menuliskan apa yang diketahui dan yang ditanyakan sesuai dengan maksud soal, kemudian kesalahan dalam mentransformasi rumusrumus himpunan dan kesalahan keterampilan proses dalam menggunakan langkah-langkah yang tepat dalam penyelesaian soal.

Dubinsky dan McDonald (Ningsih, 2016) mengemukakan bahwa untuk mengetahui bagaimana siswa dalam memahami konsep matematika seperti materi aljabar, statistika, kalkulus, dan topik matematika lainnya dapat menggunakan teori APOS. Penelitian yang dilakukan oleh Asiala, Brown, De-Vries, Dubinsky, Mathews, \& Thomas (1997) menyatakan bahwa teori APOS dapat digunakan untuk mengetahui peningkatan nyata dalam pembelajaran matematika yang kompleks dan abstrak serta dapat mengetahui pengetahuan siswa dalam membuktikan suatu teorema, memberikan contoh dan menyelesaikan masalah. Oleh karena itu, perlunya melakukan penelitian tentang profil pemahaman siswa pada materi himpunan berdasarkan perbedaan kemampuan matematika ditinjau dari Teori APOS.

Menurut Asiala, Brown, De-Vries, Dubinsky, Mathews, dan Thomas (2001), teori APOS adalah adalah suatu teori konstruktivitis tentang bagaimana kemungkinan tercapainya suatu pembelajaran konsep matematika. Teori APOS terdiri dari aksi, proses, objek dan skema. Suryadi (2011) menyatakan bahwa aksi merupakan suatu aktivitas mental yang dapat diulang dengan suatu cara yang eksplisit atau gamblang. Sedangkan Seseorang dikatakan mengalami suatu proses tentang sebuah konsep, apabila berpikirnya terbatas pada ide matematika yang dihadapinya serta ditandai dengan munculnya kemampuan untuk melakukan refleksi terhadap ide matematika tersebut. Kemudian, seseorang dikatakan telah memiliki konsepsi objek apabila seseorang telah mampu memperlakukan ide atau konsep tersebut sebagai sebuah objek kognitif dalam melakukan aksi atas suatu objek, serta mampu memberikan penjelasan tentang sifat-sifatnya. Selanjutnya, suatu skema dari suatu materi matematika tertentu adalah suatu hubungan antara aksi, proses, objek, dan skema lainnya di dalam pikiran atau otak individu.

Skema memiliki peranan penting pada Teori APOS karena merupakan orientasi dari perkembangan pengetahuan individu. 
Menurut Piaget (Dubinsky \& McDonald, 2000) skema dibagi menjadi tiga yang biasa disebut dengan skema triad terdiri dari level intra (level terendah), inter (level menengah) dan trans (level tertinggi).

Berdasarkan latar belakang tersebut maka penelitan ini bertujuan untuk mengungkap bagaimana profil pemahaman materi himpunan oleh siswa berdasarkan perbedaan kemampuan matematika ditinjau dari teori APOS. Penelitian ini diharapkan mampu memberikan gambaran kepada guru bagaimana pemahaman konsep siswa pada materi himpunan berdasarkan kemampuan matematika ditinjau dari teori APOS.

\section{Metode}

Jenis penelitian ini adalah kualitatif yang bersifat deskriptif. Subjek penelitian ini merupakan 3 siswa kelas VIII MTs Negeri Ngablak Magelang tahun ajaran 2018/2019. Subjek dipilih berdasarkan pertimbangan: (1) Sudah belajar himpunan, (2) Terdiri dari berkemampuan matematika tinggi, sedang dan rendah, (3) bersedia terlibat di dalam penelitian ini, 4) Direkomendasikan oleh guru matematikanya. Subjek dipilih berdasarkan nilai akhir semester yang kemudian dikelompokkan menjadi siswa dengan kemampuan matematika tinggi, sedang, dan rendah. Berdasarkan pengelompokkan tersebut kemudian dipilih masing-masing satu dari ketiga kemampuan matematika tersebut atas hasil diskusi bersama dengan guru. Sehingga didapati subjek NB 252 (berkemampuan matematika tinggi), AN (Berkemampuan matematika sedang) dan YG (berkemampuan matematika rendah).

Instrumen pengambilan data pada penelitian ini terdiri atas instrumen utama dan instrumen bantu. Instrumen utama adalah peneliti itu sendiri dan instrumen bantu terdiri atas soal tes, pedoman wawancara dan dokumentasi. Soal tes terdiri atas 5 soal mengenai himpunan yang sudah divalidasi. Soal 1 tentang menuliskan himpunan bagian, soal 2 tentang banyaknya himpunan bagian, soal 3 tentang menggambar diagram venn kemudian soal 4 dan 5 merupakan soal cerita tentang himpunan. Wawancara dilakukan secara mendalam untuk mendapatkan data lengkap yang dikembangkan oleh peneliti. Hasil wawancara ditulis dalam bentuk transkip wawancara. sedangkan dokumentasi berupa foto dan rekaman suara

\section{Hasil dan Pembahasan}

Hasil penelitian berupa profil pemahaman himpunan oleh siswa

Tabel 1.

Hasil Pemahaman Himpunan Berdasarkan Perbedaan Kemampuan ditinjau dari Teori

\begin{tabular}{|c|c|c|c|}
\hline \multicolumn{4}{|c|}{ APOS } \\
\hline \multirow{2}{*}{$\begin{array}{l}\text { Teori } \\
\text { APOS }\end{array}$} & \multicolumn{3}{|c|}{ Subjek } \\
\hline & $\begin{array}{c}\text { NB } \\
\text { (Tinggi) }\end{array}$ & $\begin{array}{c}\text { AN } \\
\text { (Sedang) }\end{array}$ & $\begin{array}{c}\text { YG } \\
\text { (Rendah) }\end{array}$ \\
\hline Aksi & $\sqrt{ }$ & $\mathrm{V}$ & $\mathrm{V}$ \\
\hline Proses & V & V & - \\
\hline Objek & V & - & - \\
\hline $\begin{array}{c}\text { Skema ( } \\
\text { Trans, } \\
\text { Inter atau } \\
\text { Inta) }\end{array}$ & Trans & Inter & Intra \\
\hline Ketera & $n: v=N$ & nenuhi I & kator \\
\hline
\end{tabular}

Mosharafa: Jumal Pendidikan Matematika Volume 8, Nomor 2, Mei 2019 Copyright @ 2019 Mosharafa: Jurnal Pendidikan Matematika 
berdasarkan perbedaan kemampuan matematika ditinjau dari teori APOS. Berikut hasil analisis yang diperoleh pada tabel 1 menunjukkan hasil pemahaman himpunan berdasarkan perbedaan kemampuan ditinjau dari teori APOS. Kemudian akan dijabarkan berdasarkan kemampuan matematika.

\section{A. Profil Pemahaman Himpunan oleh Siswa berkemampuan Matematika Tinggi}

Hasil penelitian menunjukkan bahwa subjek berkemampuan matematika tinggi yaitu NB, telah mampu melakukan tahapan APOS. Pada tahap aksi subjek NB mampu menentukan anggota himpunan dari himpunan kata "MATEMATIKA" dan "NUSANTARA" pada saat pertama kali mengerjakan, $N B$ menuliskan $\{\mathrm{N}, \mathrm{U}, \mathrm{S}, \mathrm{A}$, $N, T, A, R, A\} \operatorname{dan}\{M, A, T, E, M, A, T, I, K$, A) kemudian setelah subjek NB memeriksa pekerjaannya kembali, subjek NB mengubah jawabannya menjadi $\{\mathrm{N}, \mathrm{U}, \mathrm{S}$, A, T, R\}. Pada saat wawancara subjek NB juga sudah mampu mengenali apa yang diketahui dari soal dan apa yang ditanyakan dari soal. Ketika peneliti bertanya apa yang diketahui dan ditanya

1. Tulis dalam bentuk himpunan kata-kata berikut.

a. NUSANTARA

b. MATEMATIKA

$$
\begin{aligned}
& a=\{N, U, S, A, T, R\} \\
& b=\{M, A, T, E, I, K\}
\end{aligned}
$$

Gambar 1. Potret hasil pekerjaan NB nomor 1 dari soal, subjek NB langsung menjawab bahwa yang diketahui dari soal adalah dua kata tersebut yaitu "MATEMATIKA" dan "NUSANTARA" Kemudian yang ditanyakan dari soal adalah himpunan yang terbentuk dari kedua kata tersebut.

Pada tahap proses (lihat gambar 1), subjek NB menuliskan apa yang diketahui yaitu $A=\{1,2,3,4\}$. Kemudian NB menuliskan apa yang ditanya yaitu menuliskan banyak himpunan bagian dari A. Selanjutnya NB menentukan bagaimana mencari banyaknya himpunan bagian dengan menggunakan rumus $2^{n}$. Kemudian karena anggota himpunan ada 4 yaitu 1, 2, 3, 4, maka menjadi $2^{4}$, selanjutnya NB menjabarkannya menjadi $2 \times 2 \times 2 \times 2$. sehingga didapatkan hasil 16.

Subjek NB juga menuliskan kesimpulan yang didapatkan yaitu subjek menuliskan bahwa banyak himpunan bagian dari $A$ adalah 16. Pada saat wawancara ketika peneliti menanyakan apakah ada cara lain selain cara yang dituliskan NB. Subjek NB menjawab bahwa dari soal tersebut dapat

2. Diketahui : Himpunan $A=\{1,2,3,4\}$

Tentukan banyak himpunan bagian dari A!

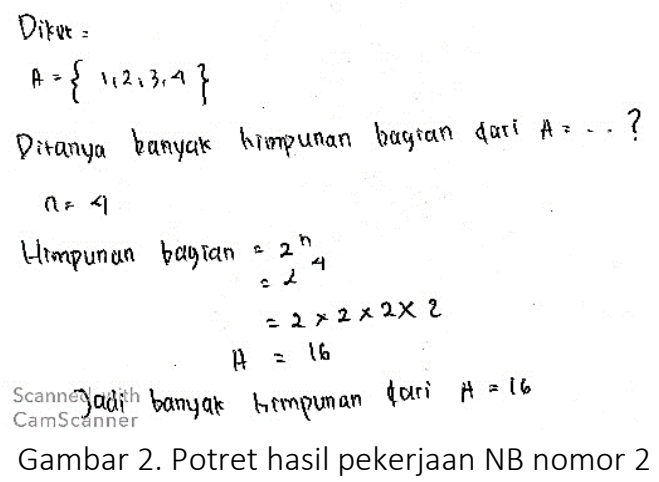


juga menggunakan cara mendaftar anggotanya seperti himpunan yang terdiri satu anggota misalnya \{\}$,\{1\},\{2\},\{3\},\{4\}$. Kemudian himpunan dengan dua anggota misalnya $\{1,2\}$ dan seterusnya hingga himpunan dengan 4 anggota.

Subjek NB mampu menggambarkan diagram Venn dengan cara menuliskan terlebih dahulu apa yang diketahui dari soal (lihat gambar 2) yaitu NB menuliskan $S=\{0,1,2,3,4,5,6,7,8,9\}$. Kemudian NB menuliskan $A=\{1,3,5,7\}$ dan $B\{2,4,6,8\}$. Selamjutnya subjek NB menggambar diagram Venn seperti yang terlihat pada gambar 3. Perlakuan yang sama juga subjek berikan pada soal 3b yaitu subjek menuliskan yang diketahui $S=\{0,1,2,3,4$, $5,6,7,8,9$ kemudian menuliskan $C=\{1,3$, $5,7,9\}$ dan $D=\{2,4,6,8\}$ serta $E=\{2,3,5$, 7\}. Lalu subjek NB menggambarkan diagram venn. Pada wawancara yang sudah dilakukan subjek NB mengetahui bahwa satu lingkaran melambangkan satu himpunan dan subjek mengenali bahwa persegi melambangkan himpunan semestanya serta subjek NB mengetahui bahwa pertemuan antara dua lingkaran merupakan irisan dari dua himpunan.

Pada tahap skema, subjek NB mampu mengerjakan soal tentang penerapan pada materi himpunan dengan tepat (lihat gambar 3). NB mampu mengaitkan antara aksi, proses dan objek sehingga membentuk suatu skema. Pada nomor 4 subjek menuliskan apa yang diketahui yaitu $S=36$, IPA = 7, MTK = 9 dan IPA+MTK $=5$. Kemudian subjek NB menuliskan apa yang ditanya yaitu banyak siswa yang tidak 254 gemar keduanya. Subjek NB menggunakan cara mengurangkan 7 dengan 5 kemudian menambahkan dengan 9 sehingga dari operasi tersebut didapati hasil 11 kemudian dari 36 dikurangkan dengan 11 sehingga mendaptakan hasil akhir 25 orang yang tidak menggemari keduanya. Subjek NB mampu menyimpulkan jawaban yang didapatkan dan mampu menggambarkan diagram venn.

Subjek NB masuk pada kategori skema trans (lihat gambar 4). Karena subjek mampu mengaitkan antara aksi, proses dan objek sehingga menjadi skema yang koheren. Pada saat wawancara subjek NB juga mengevaluasi jawabannya setelah selesai mengerjakan.

\section{B. Profil Pemahaman Himpunan oleh Siswa Berkemampuan Matematika Sedang}

Hasil Penelitian menunjukkan bahwa subjek berkemampuan matematika

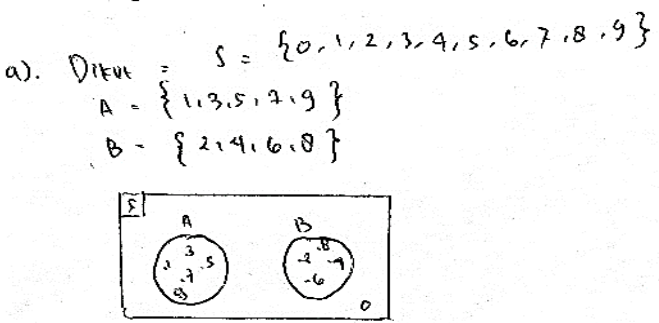

b). Dikut $=S=\{0,1,2,3,4,5,6,7,8,9\}$

$$
\begin{aligned}
& C=\{1,3,5,7,9\} \\
& D \sim\{2,4,6,8\} \\
& E=\{2,3,5,7\}
\end{aligned}
$$

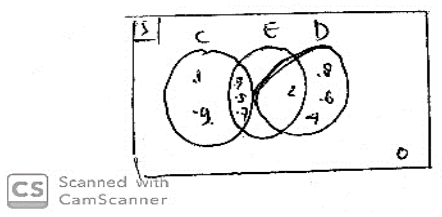

Gambar 3. Potret hasil pekeriaan NB nomor 3

Mosharafa: Jumal Pendidikan Matematika Volume 8, Nomor 2, Mei 2019 Copyright $\odot 2019$ Mosharafa: Jurnal Pendidikan Matematika 
sedang yaitu subjek AN telah mampu melakukan aksi dan proses namun belum dapat membangun suatu objek sehingga subjek belum dapat menghubungkan objek dengan skema lain yang subjek punya.

Pada tahap aksi, subjek AN mampu menentukan anggota himpunan dari suatu himpunan kata-kata. Subjek AN menuliskan $\{N\},\{U\},\{S\},\{A\},\{T\},\{R\}$ dan $\{M\},\{A\},\{T\},\{E\}, \quad\{\mid\},\{K\}$ sebagai jawabannya. Subjek AN juga mampu menyebutkan apa yang diketahui dan apa yang ditanyakan dari setiap soal yang diberikan. Hal ini disampaikan subjek AN pada saat wawancara, subjek AN menyampaikan bahwa yang diketahui dari soal adalah 2 kata yaitu NUSANTARA dan MATEMATIKA.

Pada tahap proses, subjek AN sudah mampu menentukan banyaknya himpunan bagian dari himpunan $A=\{1,2,3,4\}$. Subjek AN menggunakan langkah pengerjaan soal dengan cara mendaftar

Dikut :

$s=36$

$P Q P=7$

mik $=9$

LQP +MTK $=5$

Ditanya banyak siswa yang tidak gemar keduanya $=\cdots$ ?

Yang tidak gemar keduanyo $x_{\ldots} .$. ?

$36=7-5+9+x$

$x=25$ orang

Jadi yang tidak gomar keduanya adalath 25 orang

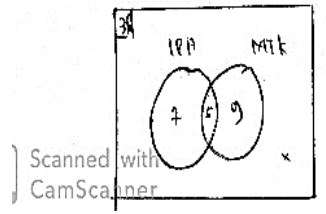

Gambar 4. Potret hasil pekerjaan NB nomor 4 himpunan-himpunan yaitu subjek menuliskan \{\}$,\{1\},\{2\},\{3\},\{4\},\{1,2\},\{1,3\}$, $\{1,4\},\{2,3\},\{2,4\},\{3,4\},\{1,2,3\},\{1,2,4\}$, $\{2,3,4\},\{1,2,3,4\}$.

Subjek mampu menjelaskan dengan baik jawaban yang subjek tulis pada lembar soal tes. Namun subjek tidak mengetahui notasi himpunan kosong. Hal ini didapati pada saat wawancara. Ketika peneliti menanyakan tentang lambang untuk himpunan kosong subjek menjawab bahwa itu hanya untuk awalan saja saat mengerjakan soal tentang banyaknya himpunan bagian.

Subjek AN belum mampu menggambar diagram venn dengan benar, subjek juga belum mampu memahami notasi dari himpunan (lihat gambar 5). Subjek juga belum mampu membedakan lambang gabungan dan irisan. Hal ini dapat dilihat dari jawaban subjek AN saat membuat diagram venn karena subjek belum dapat menjelaskan jika satu lingkarang melambangkan satu himpunan dan pertemuan antara dua himpnan disebut

$a$
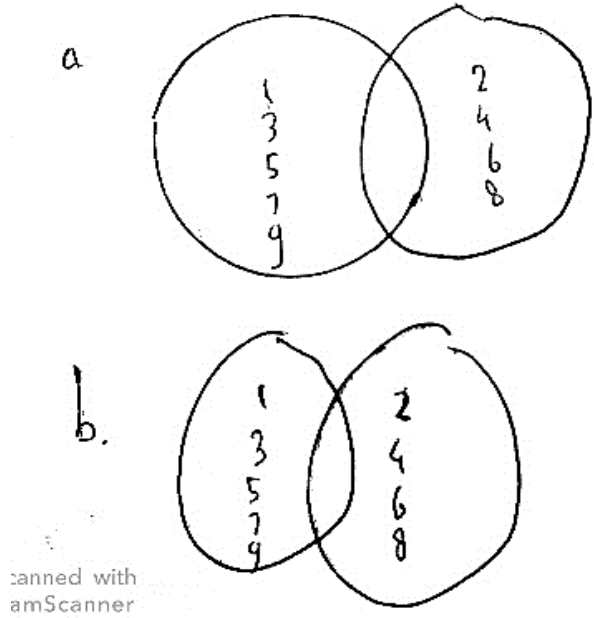

Gambar 5. Potret hasil pekerjaan AN nomor 3

Mosharafa: Jumal Pendidikan Matematika 
dengan irisan. Subjek juga belum mampu mengetahui notasi dari himpunan kosong.

Pada tahap skema, subjek AN sudah mampu melakukan aksi dan proses walaupun belum sempurna (lihat gambar 6). Subjek AN belum mampu menghubungkan suatu aksi dan proses menjadi suatu objek sehingga subjek belum dapat membentuk suatu skema yang koheren. Pada langkah pengerjaan subjek menuliskan $15+19+25+$ $12+7+9=72$.

Kemudian AN menuliskan $43+35=$ $78-72$ sehingga didapatkan hasil 6 orang. Hal ini dapat dilihat pada jawaban subjek pada soal nomor 5 yang menunjukkan pemahaman subjek pada level skema (lihat gambar 6).

Pada saat wawancara subjek AN mampu menyebutkan apa yang diketahui dan apa yang ditanyakan namun belum dapat mengubah apa yang diketahui menjadi suatu diagram venn. Kemudian langkah pengerjaannya pun subjek juga belum mampu mengerjakan dengan tepat (lihat gambar 6). Pada soal nomor 5 ini subjek AN kebingungan karena yang
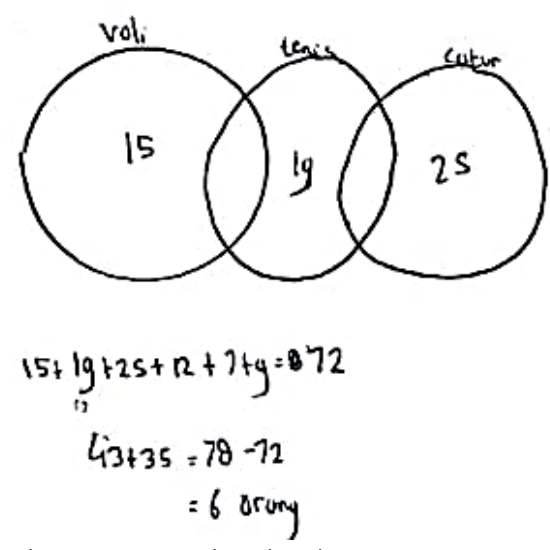

Gambar 6. Potret hasil pekerjaan AN nomor 5 diketahui terlalu banyak hal tersebut disampaikan subjek AN pada saat wawancara. subjek AN juga belum melakukan pengecekan ulang atau evaluasi terhadap jawabannya.

\section{Profil Pemahaman Himpunan oleh Siswa Berkemampuan Matematika Rendah}

Hasil penelitian menunjukkan bahwa subjek YG mampu melakukan aksi namun kebingungan saat melakukan proses sehingga tidak dapat menghubungkannya menjadi objek.

Pada tahap aksi subjek YG mampu menentukan himpunan dari dua kata yaitu "MATEMATIKA" dan "NUSANTARA". Subjek YG juga mampu menyebutkan apa yamg diketahui dan ditanyakan dari setiap soal yang diberikan. Berikut potret jawaban YG pada soal nomor 1 yang menunjukkan pemahaman subjek pada level aksi (lihat gambar 7).

Pada gambar 8, subjek YG mampu menuliskan langkah-langkah berdasarkan pengetahuan atau pemahamannya namun masih belum tepat. pada soal nomor 2 subjek YG hanya membolak-balik anggota

1. Tulis dalam bentuk himpunan kata-kata berikut.

a. NUSANTARA

b. MATEMATIKA

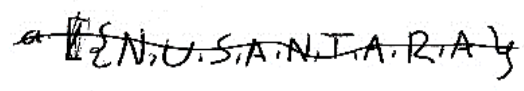

b. \{

a. $\{N, U, S, A, T, R\}$

b. $\{M, A, T, E, I, K\}$

S. Scanned with

Gambar 7. Potret hasil pekerjaan YG nomor 1 
himpunannya saja seperti $\{1,2,3,4\}$ kemudian $\{2,3,4,1\},\{3,4,2,1\}$, dan $\{4,3$, $2,1\}$ sehingga subjek YG menemukan bahwa banyak himpunan bagian dari A ada 4. subjek YG mengakui bahwa subjek merasa kebingungan dikarenakan lupa cara mengerjakannya. Hal tersebut disampaikan YG pada saat wawancara. Berikut potret jawaban YG pada soal nomor 2 yang menunjukkan pemahaman YG pada level proses (lihat gambar 8).

Pada tahap objek subjek YG mampu menggambar diagram Venn namun masih kurang tepat. Subjek YG mampu mengetahui bahwa satu lingkaran mewakili satu himpunan namun YG belum mampu mengetahui apa yang disebut irisan dan gabungan dna kemudian mengubahnya menjadi suatu diagram venn.

Pada tahap skema, subjek YG mampu melakukan aksi namun kebingungan dalam melakukan proses sehingga belum dapat menghubungkan aksi dan proses menjadi suatu objek sehingga menjadi suatu skema. Subjek YG memahami bahwa satu lingkaran mewakili satu himpunan sehingga subjek YG menggambar suatu diagram venn seperti pada gambar $3 c$ di

$$
\begin{aligned}
& A=\{2,1,4,3\} \\
&=\{4,2,3,1\} \\
&=\{3,1,4,2\} \\
&=\{1,4,2,3\} \\
& \text { Jadi banyah himpunan bagian dari } A=4 .
\end{aligned}
$$

Gambar 8. Potret hasil pekerjaan YG nomor 2 atas. Subjek YG menuliskan langkahlangkah pengerjaan dengan cara menjumlahkan semua yang diketahui yaitu subjek menuliskan $15+23+19+7+$ 9. Kemudian subjek YG mendapati hasil 219. Subjek $Y G$ juga ragu terhadap jawabannya. Subjek YG mengakui hal tersebut ketika wawancara belangsung subjek YG merasa kebingungan dan belum mampu menjelaskan apa yang dia tulis dengan jelas.

Hasil penelitian di atas menunjukkan bahwa level pemahaman siswa yang menjadi subjek penelitian tentang topik himpunan berdasarkan teori APOS berbeda-beda satu dengan lainnya. Subjek berkemampuan tinggi, sedang dan rendah memiliki pemahaman pada level aksi dimana ke tiga subjek sudah mampu mengaitkan anatara apa yang diketahui dengan yang ditanyakan. hal ini juga sejalan dengan penelitian yang dilakukan oleh Sholihah dan Mubarok (2016) yang meneliti tentang pemahaman integral tak tentu berdasarkan teori APOS menunjukkan hasil bahwa mahasiswa yang memiliki kemampuan matematika tinggi, sedang dan rendah mampu mengaitkan apa yang diketahui dan ditanyakan pada soal tahapan aksi. Hal yang sama juga ditemukan pada penelitian Yuliana \& Ratu (2018) bahwa subjek berkemampuan matematika rendah hanya mampu sampai pada tahap aksi.

Pada tahapan objek subjek yang memiliki kemampuan tinggi dapat mengubah suatu kalimat matematika menjadi suatu objek melalui diagram venn 
secara umum. Subjek dengan kemampuan matematika sedang belum dapat mengorganisaikan suatu aksi dan prosesnya menjadi suatu objek atau belum dapat mengubah suatu masalah matematika pada topik himpuan menjadi suatu diagram venn.

Subjek berkemampuan rendah juga belum dapat mengorganisasikan suatu aksi dan proses menjadi suatu objek. Kemudian subjek dengan kemampuan matematika sedang dan rendah belum mampu memahami simbol matematika terutama pada materi himpunan sehingga sulit untuk memecahkan suatu persoalan. Hal ini didukung oleh penelitian yang dilakukan Nurrizbaeni \& Zanthy (2018) yang meneliti tentang kemampuan komunikasi dan disposisi matematika siswa pada materi himpunan menunjukkan hasil bahwa siswa masih kurang dalam menyelesaikan masalah pada materi himpunan disebabkan oleh kurangnya pemahaman siswa dalam membaca simbol matematika, siswa tidak suka belajar atau membaca kembali buku pelajaran, dan siswa tidak terbiasa dalam mengintepretasikan soal dalam bentuk operasional matematik.

Pada tahap skema subjek berkemampuan tinggi memiliki skema trans karena subjek telah mampu melakukan suatu aksi dan proses untuk membangun sebuah konsep dan menghubungkan objek dengan skema awal. Subjek berkemampuan sedang memiliki skema Inter dalam mengerjakan namun subjek belum dapat memilih menghubungkan objek yang subjek punya dengan skema lain untuk menyelesaikan soal aplikasi himpunan.

Sedangkan siswa berkemampuan rendah memiliki skema pada kategori intra dikarenakan siswa mengalami sedikit kesulitan sehingga membangun objek pun juga mengalami hambatan. Berdasarkan kategori skema yang didapatkan peneliti, temuan yang sama juga didapatkan oleh Febriana \& Budiarto, (2012) yang berusaha meneliti kemampuan siswa dalam menyelesaikan soal fungsi kuadrat berdasarkan teori APOS didapatkan hasil bahwa siswa yang berkemampuan tinggi mampu melakukan suatu aksi, proses dan objek sehingga membentuk skema trans, kemudian siswa berkemampuan sedang mampu melakukan aksi dan objek saja sehingga siswa masuk pada skema inter, sedangkan siswa berkemampuan rendah hanya mampu melakukan aksi tetapi belum mampu melakukan proses dengan sempurna sehingga siswa memiliki skema Intra.

Berdasarkan hasil analisis dan pembahasan di atas dapat disimpulkan bahwa siswa yang memiliki kemampuan matematika tinggi dalam menyelesaikan soal himpunan berdasarkan teori APOS telah mampu melakukan aksi, proses, objek dan skema. Siswa mampu melakukan aksi dan proses serta mampu menghubungkannya menjadi objek dengan skema awal yang telah dimiliki sebelumnya dalam menyelesaikan soal himpunan. Berdasarkan hal tersebut siswa Mosharafa: Jurnal Pendidikan Matematika Volume 8, Nomor 2, Mei 2019 Copyright $\odot 2019$ Mosharafa: Jurnal Pendidikan Matematika 
berkemampuan tinggi termasuk pada kategori level skema trans.

Siswa yang memiliki kemampuan matematika sedang dalam menyelesaikan soal himpunan berdasarkan teori APOS mampu melakukan aksi dan proses untuk membangun suatu objek. Namun, siswa belum mampu menghubungkan objek dengan skema lain yang ia punya untuk menyelesaikan soal himpunan. Berdasarkan hal tersebut siswa berkemampuan sedang termasuk pada kategori level skema inter.

Siswa yang memiliki kemampuan matematika rendah dalam menyelesaikan soal himpunan berdasarkan teori APOS mampu melakukan aksi namun mengalami kesulitan pada bagian proses sehingga tidak dapat membangun suatu objek. Berdasarkan hal tersebut siswa berkemampuan rendah termasuk pada kategori level skema intra.

\section{Penutup}

Perbedaan level kemampuan matematika siswa sebanding lurus dengan perbedaan kemampuan pemahaman himpunannya. Dalam proses belajar dan mengajar, seorang guru harus lebih memperhatikan pemahaman dari setiap siswa dari mulai yang berkemampuan tinggi, sedang hingga rendah. Sehingga guru dapat menggunakan metode atau strategi dalam mengajar agar materi pembelajaran dapat tersampaikan dengan baik kepada siswa. Penelitian ini dapat dilanjutkan yang difokuskan pada pemahaman siswa berdasarkan teori APOS

Mosharafa: Jurnal Pendidikan Matematika

Volume 8, Nomor 2, Mei 2019

Copyright @ 2019 Mosharafa: Jurnal Pendidikan Matematika pada materi-materi lainnya atau dengan memperhatikan variabel-variabel lain seperti gender, gaya belajar dan lain-lain.

\section{DAFtar Pustaka}

Adilistiyo, M. E. (2017). Analisis Kesalahan Siswa SMP Kelas VII dalam Menyelesaikan Soal pada Materi Himpunan. (6), 67-72.

Asiala, M., Brown, A., De-Vries, D. J., Dubinsky, E., Mathews, D., \& Thomas, K. (1997). A framework for research and Curriculum Development in Undergraduate Mathematics Education. 40, 23.

Asih, Y. R. (2018). Analisis Kesalahan Siswa dalam Menyelesaikan Soal Cerita Himpunan Kelas VII MTs Negeri Surakarta II. Journal (Canadian Dental Association), 70(3), 156-157.

Dini, M., Wijaya, T. T., \& Sugandi, A. I. (2018). Pengaruh Self Confidence Terhadap Kemampuan Pemahaman Matematik Siswa Smp. Jurnal Silogisme, 3(1), 1-7.

Dubinsky, E., \& McDonald, M. A. (2000). APOS: A Constructivist Theory of Learning in Undergraduate Mathematics Education Research. 122.

Febriana, C., \& Budiarto, mega teguh. (2012). Abstrak. 01, 1-7. Surabaya: Universitas Negeri Surabaya

Lisnani, L. (2019). Pemahaman Konsep Awal Calon Guru Sekolah Dasar tentang Pecahan. Mosharafa: Jurnal Pendidikan Matematika, 8(1), 61-70. 
Marsudi. (2011). Logika dan Teori Himpunan. Malang: Universitas Brawijaya Press.

Mulyani, A., Indah, E. K. N., \& Satria, A. P. (2018). Analisis Kemampuan Matematis Siswa SMP Pada Materi Bentuk Aljabar. Mosharafa: Jurnal Pendidikan Matematika, 7(2), 251262.

Muna, D. N., \& Afriansyah, E. A. (2016). Peningkatan Kemampuan

Pemahaman Matematis Siswa melalui Pembelajaran Kooperatif Teknik Kancing Gemerencing dan Number Head Together. Mosharafa: Jurnal Pendidikan Matematika, 5(2), 169176.

Ningsih, Y. L. (2016). Kemampuan Pemahaman Konsep Matematika Mahasiswa Melalui Penerapan Lembar Aktivitas Mahasiswa (LAM) Berbasis Teori APOS Pada Materi Turunan. Edumatica, 06(April), 1-8.

Nizam. (2016). Ringkasan Hasil-hasil Asesmen Belajar Dari Hasil UN, PISA, TIMSS, INAP. Seminar Puspendik 2016. Nurrizbaeni, N., \& Zanthy, L. S. (2018). Analisis Kemampuan Komunikasi Matematik dan Disposisi Matematik Siswa MTs Nurul Hatta Kelas VII Pada Materi Himpunan. Jurnal On Education, 01(03), 29-36.

OECD. (2016). Country Note - PISA Result from PISA 2015 (Indonesia). 1-8.

Puspitasari, P. \& Ratu, N. (2019). Deskripsi Pemahaman Konsep Siswa dalam Menyelesaikan Soal PISA pada Konten Space and Shape. Mosharafa: Jurnal
Pendidikan Matematika, 8(1), 155166.

Sholihah, U., \& Mubarok, D. A. (2016). Analisis Pemahaman Integral Taktentu Berdasarkan Teori Apos (Action, Process, Object, Scheme) Pada Mahasiswa Tadris Matematika (Tmt) lain Tulungagung. Cendekia: Jurnal Kependidikan Dan Kemasyarakatan, 14(1), 125.

Suryadi. (2011). Membangun Budaya Baru dalam Berpikir Matematika.

Yuliana, D., \& Ratu, N. (2018). Deskripsi Kemampuan Pemahaman Konsep. 5(1), 51-65.

\section{Riwayat Hidup PenUlis}

\section{Maya Winarsih}

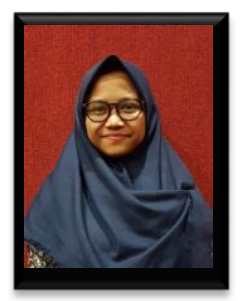

Lahir di Grobogan, 14 April 1997. Mahasiswa Prorgram Studi S1 FKIP Progdi Pendidikan Matematika Universitas kristen satya Wacana, Salatiga.

\section{Helti Lygia Mampouw S.Pd., M.Si.}

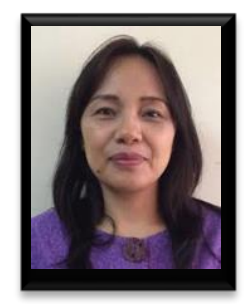

Staf pengajar di FKIP Progdi Pendidikan Matematika Universitas Kristen Satya Wacana, Salatiga. 